Transformative Philosophy 



\title{
Transformative Philosophy
}

\author{
A STUDY OF ŚANKKARA, \\ FICHTE, AND HEIDEGGER
}

JOHN A. TABER

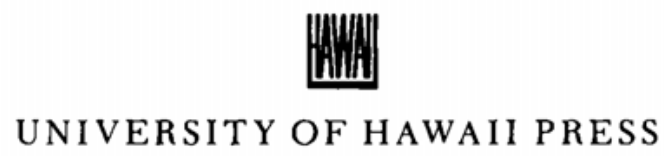

Honolulu 
(C) $198_{3}$ UNIVERSITY OF HAWAII PRESS

ALL RIGHTS RESERVED

MANUFACTURED IN THE UNITED STATES OF AMERICA

Library of Congress Cataloging in Publication Data

Taber, John A., 1948-

Transformative philosophy.

Bibliography: p.

Includes index.

1. Śankkarācārya. 2. Fichte, Johann Gottlieb,

1762-1814. 3. Heidegger, Martin, 1889-1976. I. Title.

B133.S5T27 $1983 \quad 181^{\prime} .483 \quad 83-4993$

ISBN 0-8248-0798-7 
For my parents 

Every thinker is prone to claim that his conclusions are the only logical ones, that they are necessities of universal reason, they being all the while, at bottom, accidents more or less of personal vision which had far better be avowed as such; for one man's vision may be much more valuable than another's, and our visions are usually not only our most interesting but our most respectable contributions to the world in which we play our part. What was reason given to men for, said some eighteenth-century writer, except to enable them to find reasons for what they want to think and do? - and I think the history of philosophy largely bears him out. "The aim of knowledge," says Hegel, "is to divest the objective world of its strangeness, and to make us more at home in it." Different men find their minds more at home in very different fragments of the world.

William James, A Pluralistic Universe

alam sukumārahṛdayopadeśyajanavairasyadāyin̄̄bhị kathābhị̣. citśaktyarthibhị pratyabhijñā parīkșyā.

Kșemarāja, Spandanirṇaya 
